\title{
Tiede päätösten pohjana - terveydeksi ja turvaksi
}

\author{
Jaana Husu-Kallio \\ Euroopan Komissio, Pääosasto terveys ja kuluttaja-asiat
}

Euroopan yhteisössä elintarvikelainsäädännön kehittämisen periaatteena on korkeatasoinen terveyden suojelu ja sitä sovelletaan elintarvikkeiden kauppaan sekä sisämarkkinoilla että kansainvälisesti. Elintarvikkeiden ja rehujen vapaa liikkuvuus voidaan saavuttaa ainoastaan sillä edellytyksellä, että niiden turvallisuutta koskevat vaatimukset eivät merkittävästi poikkea toisistaan eri jäsenvaltioissa.

Elintarvikkeiden turvallisuus ja kuluttajien etujen suojaaminen on entistä tärkeämpää. Elintarvikelainsäädäntöä kehitettäessä avoimuus on yksi työn peruspilareista. Kuluttajien ja kansainvälisten kauppakumppaniemme on pystyttävä luottamaan päätöksentekojärjestelmäämme, sen tieteelliseen perustaan sekä sen riippumattomuuteen. Jotta elintarvikelainsäädännön tieteelliseen perustaan voitaisiin luottaa, riskinarvioinnit on toteutettava riippumattomasti, objektiivisesti ja avoimesti, ja niiden on perustuttava uusimpiin saatavilla oleviin tieteellisiin tutkimuksiin.

\section{Taustaa}

Tieteellistä riskinarviointia ja päätöstentekoa eriytettiin toisistaan Euroopan komissiossa jo vuonna 1997, jolloin silloiset komission tieteelliset komiteat siirrettiin nykyisen kuluttaja- ja terveysasioiden pääosaston alaisuuteen. Tieteellisten komiteoiden painopisteenä olivat: erityisosaaminen, avoimuus ja riippumattomuus. Euroopan komissio esitti suunnitelmansa uutta elintarvikepolitiikkaa varten nk. valkoisessa kirjassa vuonna 2000. Siitä sai alkunsa elintarvike- ja kuluttajalainsäädännön nykyaikaistaminen johdonmukaiseksi kokonaisuudeksi, jossa tieteellistä neuvonantoa pyrittiin edelleen vahvistamaan. Euroopan elintarviketurvallisuusviranomaisen (EFSA) perustamisen keskeisenä tavoitteena oli kuluttajien luottamuksen palauttaminen, jota erilaiset elintarvikekriisit olivat horjuttaneet.

Euroopan parlamentin ja neuvoston asetus (No 178/2002) vuodelta 2002 säätää yleiset elintarvikelainsäädännön periaatteet sekä toimenpiteet liittyen elintarvikkeiden turvallisuuteen. Uusi asetus erottaa riskinarvioinnin ja riskinhallinnan entistä selvemmin erilleen toisistaan. Sen mukaan riskinhallinta, päätöksen teko, kuuluu edelleen komission, jäsenmaiden ja parlamentin toimialaan. Komissio vastaa Euroopan Unionin lainsäädännöstä kansainvälisellä tasolla ja tarvittaessa puolustaa omaa lainsäädäntöään esim. maailman kauppajärjestössä (WTO). EFSA puolestaan vastaa riskinarvioinnista antamalla tieteellisiä lausuntoja sekä tiedottamalla riskeistä, myös suoraan kuluttajille.

Nykyinen uudistunut elintarvikelainsäädäntö perustuu jo suurelta osin tieteellisiin asiantuntijalausuntoihin. Esimerkiksi kaikki ruoan lisäaineet ovat käyneet läpi riskinarvioinnin ennen niiden hyväksymistä. Tiede tuottaa nopeasti uutta tietoa, joka saattaa kumota tai muuttaa entisiä käsityksiä. Siksi on tärkeää, että päätöksiä tehdessä otetaan aina uusimmat tutkimustulokset ja tieteelliset arviot huomioon. Tämä on yksi EFSA:n sekä komission suurimmista haasteista. 


\section{Tieteellinen erityisosaaminen, riippumattomuus ja avoimuus}

EFSA:n tehtävänä on antaa tieteellisiä lausuntoja sekä tieteellisteknistä tukea yhteisön lainsäädännön ja politiikkojen tarpeisiin kaikilla aloilla, joilla on vaikutusta elintarvikkeiden ja rehujen turvallisuuteen. Tiedekomitea ja pysyvät tiedelautakunnat ovat vas-tuussa tieteellisten lausuntojen antamisesta oman asiantuntemuksen alalla, kuten esimer-kiksi kasvien terveyttä, kasvinsuojeluaineita ja niiden jäämiä käsittelevä lautakunta tai eläinten terveyttä ja hyvinvointia käsittelevä lautakunta.

Elintarvikkeiden ja rehujen turvallisuutta koskevat tieteelliset ja tekniset kysymykset ovat muuttuneet entistä tärkeämmiksi ja monimutkaisemmiksi. Komissio edellyt-tää, että tieteellisten lausuntojen on oltava mahdollisimman korkeatasoista. Tiedekomite-an lautakuntien jäsenten on oltava alansa parhaita asiantuntijoita, jotka on valittu avoi-men hakumenettelyn perusteella. Tiedekomitean ja tiedelautakuntien jäsenet sitoutuvat toimimaan kaikista ulkopuolisista, kuten teollisuuden etunäkökohdista tai politiikan vai-kutteista riippumattomasti.

EFSA:n johtokunta, johon minäkin kuulun tällä hetkellä komission edustajana, vahvistaa viranomaisen sisäiset säännöt ja vuosittaisen työohjelman. Johtokunta myös varmistaa, että ohjelma perustuu yhteisön lainsäädäntöön ja politiikkaan liittyviin paino-pisteisiin elintarviketurvallisuuden alalla.

Komissio edellyttää riskinarvioinnissa avoimuutta. Kansalaisilla on oikeus saada tietoa, miten tieteelliseen lausuntoon ja suosituksiin on päädytty. Lausunnot julkaistaan heti internetissä, jotta kaikki asiasta kiinnostuneet tahot saisivat niistä tiedon. Yhteistyö jäsenvaltioiden asiantuntijoiden kanssa on välttämätöntä tiedon saannin ja ja-kamisen kannalta. Elintarviketurvallisuusviranomaisen neuvoa-antava ryhmä, joka koos-tuu jäsenvaltioiden edustajista, vaihtaa tietoja keskenään riskeistä ja kokoaa tietoa jä-senmaista. Siten jäsenvaltioilla on mahdollisuus osallistua entistä tiiviimmin myös tie-teellisiin menettelyihin.

\section{Riskiviestintä}

Elintarvikkeiden osalta on harvoin kyse ns."nolla-riskistä”. Riskiviestinnällä on sen vuoksi olennainen merkitys tiedotettaessa elintarvikkeiden turvallisuudesta kuluttajille. On tärkeää, että kuluttajat saavat oikeaa tietoa, jolloin myös voidaan vähentää turhien huolien syntymistä.

Eurooppalaisille kuluttajille suunnatuissa tiedotuskampanjoissa on tehtävä asianmukaista yhteistyötä komission, jäsenmaiden sekä elintarviketurvallisuusviranomai-sen kesken. Sekä komissiolla että elintarviketurvallisuusviranomaisella on omat roolinsa riskiviestinnässä. Oman haasteensa muodostavat alueelliset erilaisuudet ja niiden huomi-oiminen tiedotuksessa.

Komission tehtävänä on tiedottaa ja päättää toimista, joita tarvitaan takaamaan elintarvikkeiden turvallisuus. Se voi käsittää esim. raja-arvon asettamista tietyille aineille tai tietyn tuotteen vetämistä markkinoilta. Elintarviketurvallisuusviranomainen sen sijaan antaa tieteellisen kannanoton, miten suuri kyseinen riski on. Sen tiedon perusteella ko-missio voi yhdessä jäsenvaltioiden kanssa päättää minkä tasoisesta riskistä on kysymys ja miten laajoihin toimiin pitää ryhtyä.

\section{Kriisin hallinta}

Viimeaikaiset elintarvikkeiden turvallisuuteen liittyneet kriisit ovat osoittaneet, että eri osapuolten on reagoitava nopeasti ja saumattomasti. Sen vuoksi komissio on uudessa kriisitilanteen hallinnan suunnitelmassa esittänyt, miten eri tahojen tulisi toimia. Komis-sion tehtävänä on perustaa tarvittaessa kriisiyksikkö, johon elintarviketurvallisuusviran-omainen osallistuu antamalla tieteellistä ja teknistä tukea. Kriisiyksikkö tiedottaa yleisöl-le asiaan liittyvistä riskeistä ja toteutetuista toimenpiteistä. Näin turvataan luotettava tieto kuluttajille ja taataan ettei eri lähteistä tuleva tieto ole ristiriitaista. 
Kriisin hallintaan ei aina tarvita tieteellistä arviointia. Esimerkiksi jonkin kielletyn, jo terveydelle vaaralliseksi todetun aineen löytyminen rehusta tai elintarvikkeesta, johtaa aina välittömiin toimenpiteisiin haitan poistamiseksi.

Joissain tapauksissa komission ja jäsenmaiden on tarpeen toimia ns. ennalta varautumisen periaatteen mukaisesti. Vakavaa vaaraa epäiltäessä voidaan päättää väliaikaisista varotoimenpiteistä, vaikka tiedoissa olisi vielä puutteita. Tieteellisen arvioinnin edellytyksenä on luonnollisesti jo olemassa oleva tieto, joten tiedon puute voi viivästyttää riskin arviointia ja vaikuttaa siten päätöksiin mahdollisista varotoimenpiteistä.

Euroopan elintarviketurvallisuusviranomaisen yhtenä haasteena on pyrkiä tunnistamaan uusia mahdollisesti uhkaavia riskejä tiedon keruun ja verkostoitumisen kautta. Ihanteellisinta luonnollisesti on ennaltaehkäistä vaarat ennen kuin ne aiheuttavat riskin. Tämä lisää kuluttajien luottamusta järjestelmän toimivuuteen ja ruoan turvallisuuteen.

Vaikka tieteellinen riskinarviointi on näin eriytetty itsenäiseksi ja riippumattomaksi yksiköksi, Euroopan komission, elintarviketurvallisuusviranomaisen ja jäsenmaiden on tarpeen entistä tiiviimmin jakaa tietoa ja toimia yhdessä riskinarvioinnissa, hallinnassa ja viestinnässä entistä terveellisempien ja turvallisempien elintarvikkeiden takaamiseksi.

Tässä työssä riittää vielä paljon tekemistä, vaikka Eurooppa onkin - ja pyrkii jatkossakin olemaan - suunnannäyttäjä elintarviketurvallisuuden takaamiseksi periaatteella "pellolta pöytään". 